writer in the Florida Bulletin 79, page 313. Professor Gossard also mentions this method of destroying ants in the third issue of the JourNal, June, 1908, page 190. A solution possesses certain advantages over a dry powder. There is no danger for example of ehickens picking up the particles if the former is employed. It is evident that this insecticide can be used to some extent at least against subterranean insects. More experiments are necessary to determine the limitations of this powerful insecticide along this line.

E. P. FELT

\title{
THE ECONOMIC ENTOMOLOGIST IN BUSINESS
}

B. H. I, Frost, drlington, luats.

Each year as transportation facilities improve and natural products from all parts of the globe are assembled in one place, the problems of the economic entomologist are increased. With the changes of habitat of the various species of plant growth comes the unbalancing of Nature's control of both injurious and beneficial insects. Thus, the entomologist of today cannot be simply the man of scientific knowledge, but must debase his profession by combining his science with practical business in order to fill his position to the best advantage. Will he gain or lose by this change? His remuneration will be increased to a greater or less extent according to his business ability, but his glory of achieving honors by scientific research will be lessened because of his lack of time to carly on both branches of the work.

It is the purpose of this article to show in brief the great need of commercial economic entomologists. The profession is in its infancy and might be compared to the day of the medical profession when the patient was bled for every disease. Injurious insects have increased faster than remedies or natural enemies, and this is the problem to. be overcome by our scientific and trained men. The value of all kinds of trees which suffer most from insect depredations has developed a hundred fold in the last decade. Owners everywhere are calling in vain for help to save trees which have required years to mature.

Fortunately, we have had a generation of scientific men, peers to none, who have devoted their lives to the study of insects. They have given and are giving us information, which is both complete and accurate. Our failure is our inability to make use of this research by securing and applying practical remedies. This is the field which offers unlimited opportunities to the present generation.

A proper preliminary training will be found of great service, but should be very broad in order to make a success of this work. Even 
with this preparation one is, in reality, dependent to a great degree upon the specialists who are devoting their lives to the scientific study of insects. The average land owner is not equipped by either training or experience for carrying ont the ideas of the economic entomologist. II requires a specialist who can accomplish the desired end. Unless injurious insects are checked our fruit trees, many of our ornamental trees, and, in New England, our forest trees, will be largely destroyed. The scientist, chemist, and trained workman, must all combine forces if the loss to agricultural interests is to be reduced.

No one should undertalie a business of this deseription withont supplementing his entomological training with a knowledge of some affiliated subject, such as Horticulture, Forestry, or Tree-surgery. His work of fighting insects, as a rule, covers only a short season, and must necessarily be carried on with the least possible delay. In the East, unfavorable weather conditions may deprive him of all his protits. On the other hand, very favorable conditions will give him most remmerative returms. Thus, he should make one of the abovenentioned branches the basis of his business, using his entomology as his speculative step toward the success of his enterprise.

As an illustration: A man owns a valuable orchard which is being stripled by the canker worm. He calls in a contractor, who rccorimends spraying with an arsenical poison. The season is so wet while the insect is feeding that it is impossible to do any spraying, and, consequently, the job is lost. If the contractor is equipped for horti"ultural work, he can benefit the orchard in other ways, even though he was mable to check the ravages of the insect. He will securc immediate results by pruning, fertilizing, and improving the general health of the trees, thus making them better able to resist insect. attacks.

This is me instance where he has lost nearly his entiro spraying season, which happens about once in seven or cight years. The stromgest aroument against his depending on entomological work alome is the necessity of his having skilled men. In fighting insects, a very high standard of trained laborers is required to obtain the best results. It is impossible to hold such men without giving them steady employment. To do this, work must be secured which can be held over, withont injury to the tree, to be carried on at the conrenience of these workmen. Tree-surgery or affiliated branches make this plan possible.

The business of caring for trees has made a-tremendous advancement in the last ten years, but we still have many problems to solve. The least progress has been made in handling the various insects, as 
there are still many pests which cannot even be suppressed. Chemicals used for spraying purposes very often act differently under different climatic conditions. Whether this is due to chemical changes in the poisons or to varying pathological conditions seems to be unknown. For example, tests have been made of nearly every brand of arsenate of lead (supposed to be a perfectly safe poison) and in each case, under certain conditions, burning of the foliage has resulted. If our most perfected remedy cannot be depended upon under all conditions, even when applied by trained men, the great necessity of advancement is readily apparent. This can be assured only by the entrance into business of economic entomologists.

\section{MUST THE CALYX CUP BE FILLED ?}

By M. T. Slingerlaxd, Cornell Cuiterwity

More than a decade has elapsed since I studied the codling-moth and monographed the then existing knowledge of the insect in Bulletin 142 of the Cornell Agricultural Experiment Station. Since then I have closely followed the excellent work done, both in the East and the far West, by which much new information has been gleaned regarding the life-history and methods of controlling this pest. But I was hardly prepared for the accusations that Eastern entomologists were lax and not up to date in their advice to their constituents, as set forth in the article entitled "Filling the Calyx Cup," in the Jume, 1908 , number of this JOURNAL.

Fortunately I had been making some photographs of the calyx ends of developing apples for my class work when the above article appeared. The pictures at $\mathrm{A}, \mathrm{A}, \mathrm{A}, \mathrm{A}, \mathrm{B}$ and $\mathrm{C}$ on the plate well illustrate the outer and inner calyx cavities, which are separated by the ring of stamens, with the large fleshy pistil extending up through the center. The bases of these stamens set very closely together and come up close around the pistil. I was also surprised to find that even after their tips had withered and the calyx lobes harl elosed in, the stamens remained fresh and plump at the base, and around the pistil, and thus still formed a partition or wall between the two cavities, as shown at $\mathrm{C}$. In fact so tight a barrier did the stamens form between the two cavities that I became a "donbting Thomas" as regards the assertions of some entomologists that it was absolutely neeessary to drench a tree with a spray sufficiently forceful to drive the

\footnotetext{
'Contribution from the Entomological Laboratory of Cornell University.
} 